\title{
大気プラズマ溶射法を用いた静電吸着能を有するセラミック皮膜の開発
}

\section{Development of Ceramic Coatings for Electrostatic Adsorption Force using Atmospheric Plasma Spraying}

\author{
竹 内 純 * $^{*}$ - 山崎 良* ・ 谷 和 美* \\ Jun-ichi TAKEUCHI, Ryo YAMASAKI and Kazumi TANI
}

(Received September 22, 2008)

\begin{abstract}
In state-of-the art semiconductor equipment such as dry etchers, CVD and PVD chambers as well as in the liquid crystal manufacturing industry, it is very important to consistently keep silicon wafers or glass on the susceptor. The main objectives are to improve the accuracy of both positioning and temperature control.

Generally electrostatic adsorption force is used for holding silicon wafers or glass inside of a treatment chamber. The sintered ceramics, the polymer resin, and the thermal sprayed ceramic coatings are used as the dielectric substance to isolate and protect the surface of the electrostatic chuck and limit contamination and particle generation. However, investigations of the electrostatic adsorption force through thermal sprayed ceramic coatings have been limited. In this study, a ceramic coating having the electrostatic adsorption force was developed and its basic mechanical and electrical characteristics were investigated, and compared with those of sintered ceramics.
\end{abstract}

Key Words: Atmospheric Plasma Spraying, Ceramic Coatings, Dielectric Substance, Electrostatic Adsorption

\section{1. 緒言}

半導体加工製品及び液晶の製造プロセスにおいて使用さ れるドライエッチャー、CVD、PVD などの加工装置類では 回路の高集積化に伴う微細加工の必要性から、シリコンウ エハやガラス基板のパターニング時の位置決め精度の向上 に加え、加工時の温度制御にも優れた静電吸着装置が重要 な役割を果している ${ }^{1), 2)}$ 。また、静電吸着装置は、半導体加 工容器内における環境污染物として忌避される微細な加工 粉体類の発生を抑制する効果を有することから半導体加工 製品の品質向上及び生産コストの低減にも貢献することが 知られるようになり、益々その適用分野は拡大される傾向 にある ${ }^{3), 4}$ 。

静電吸着装置の原理は、Fig. 1 に示すようにベース基板 （例えばアルミニウム合金）の表面に誘電膜を配し、その ベース基板と被吸着体（シリコンウエハやガラス）との間 に直流電圧を印加することにより静電吸着力を発生させて 吸着させるものである ${ }^{5)}$ 。

静電吸着装置において重要な役割を果たす誘電（膜）体 としては、従来からポリイミドに代表される高分子系樹脂、 アルミナ、窒化アルミなどの焼結セラミックなどが報告さ れているが1), 6)、前者は加工温度の影響を受けやすく、後者

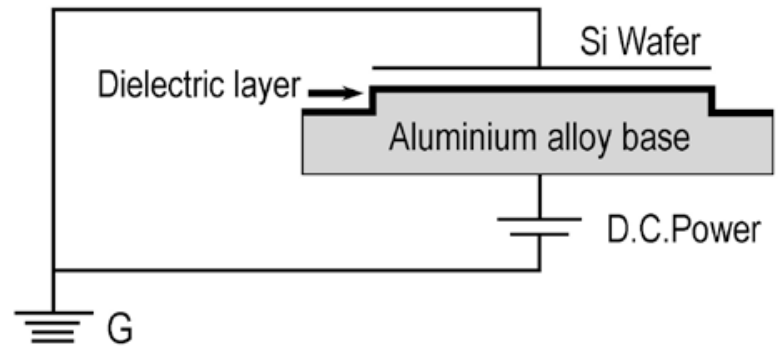

Fig. 1 Schematic description of electrostatic chuck.

は粉体の加圧成形工程と高温の焼結処理を必要とすること から、生産性に劣り、また、大型化は困難である。

本研究では、はじめに静電吸着の原理を紹介した後、大 気プラズマ溶射法によるジョンソン・ラーベックカ7)を有 する誘電皮膜の開発を目的とし、溶射材料の化学成分と体 積抵抗率の関係を明らかにする。次いで形成した溶射皮膜 の機械的及び電気特性などの静電吸着皮膜の設計に必要な 物性值を実験により求めた結果について報告する。

\section{2. 静電吸着発生の原理}

静電吸着力は Fig. 2、Fig. 3 に示すようにクーロン力と

*トーカロ株式会社溶射技術開発研究所 ( $\bar{T} 674-0093$ 兵庫県明石市二見町南二見 14番地の 3)

Thermal Spraying Technology R\&D Laboratories, TOCALO Co., Ltd. (14-3 Mnami-Futami, Futami-Cho, Akashi, Hyogo 674-0093 Japan) 


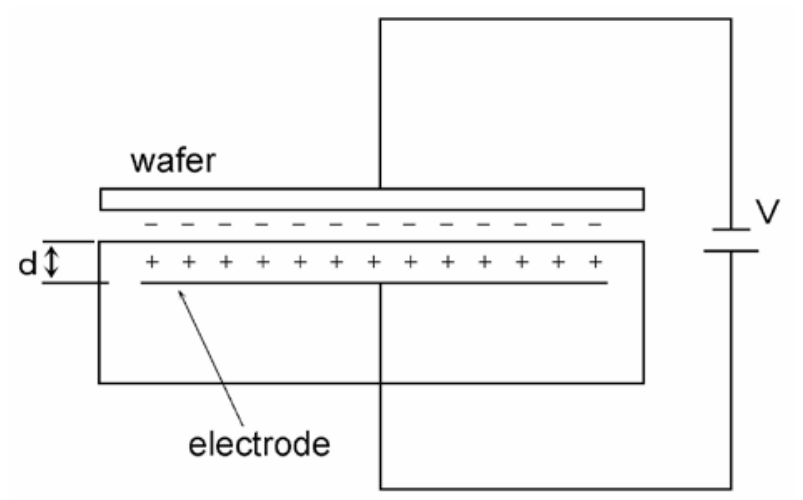

Fig. 2 Schematic of principle Coulomb's force.

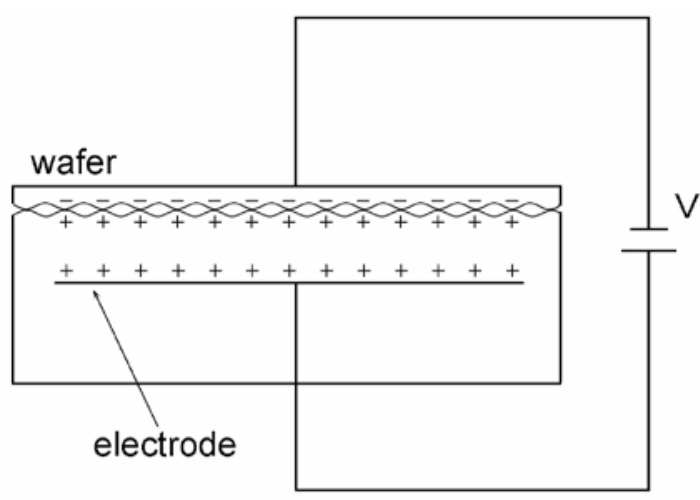

Fig. 3 Schematic of principle Johnsen-Rahbeck's force.

ジョンソン・ラーベックカの 2 種類に分類される ${ }^{4)}$ 。

(1) 誘電体を容量とするコンデンサを形成して、電極と被吸 着体間に逆極性の電荷を誘起させたクーロン力

(2) 上記クーロン力に加え、被吸着体と誘電体の界面の小さ なギャップに微少電流を流し、帯電分極して誘起される ジョンソン・ラーベックカ8)

この場合、静電吸着力はクーロンカとジョンソン・ラー ベックカにより下記の式で表される9)。

$$
F=\alpha F c+\beta F_{J R}=1 / 2 \alpha \varepsilon_{0} \varepsilon(V / d)^{2}+1 / 2 \beta \varepsilon_{0}(V / g)^{2}
$$

ここで

$$
\begin{aligned}
& F_{\mathrm{C}}: \text { クーロンカ、 } \\
& F_{J R}: \text { ジョンソン・ラーベックカ、 } \\
& \alpha, \quad \beta \text { : 係数、 } \varepsilon 0 \text { : 真空中の誘電率、 } \\
& \varepsilon: \text { 比誘電率、 } V: \text { 印加電圧、 } \\
& d: \text { 誘電体の膜厚、 } g \text { : 界面間の距離 }
\end{aligned}
$$

この 2 つの力、誘電体の体積抵抗率により発現される 領域が異なっており、一般にクーロン力は高抵抗の領域で、 ジョンソン・ラーベックカは低抵抗の領域では支配的で、 中抵抗では両方の力が発生する ${ }^{10)}$ 。
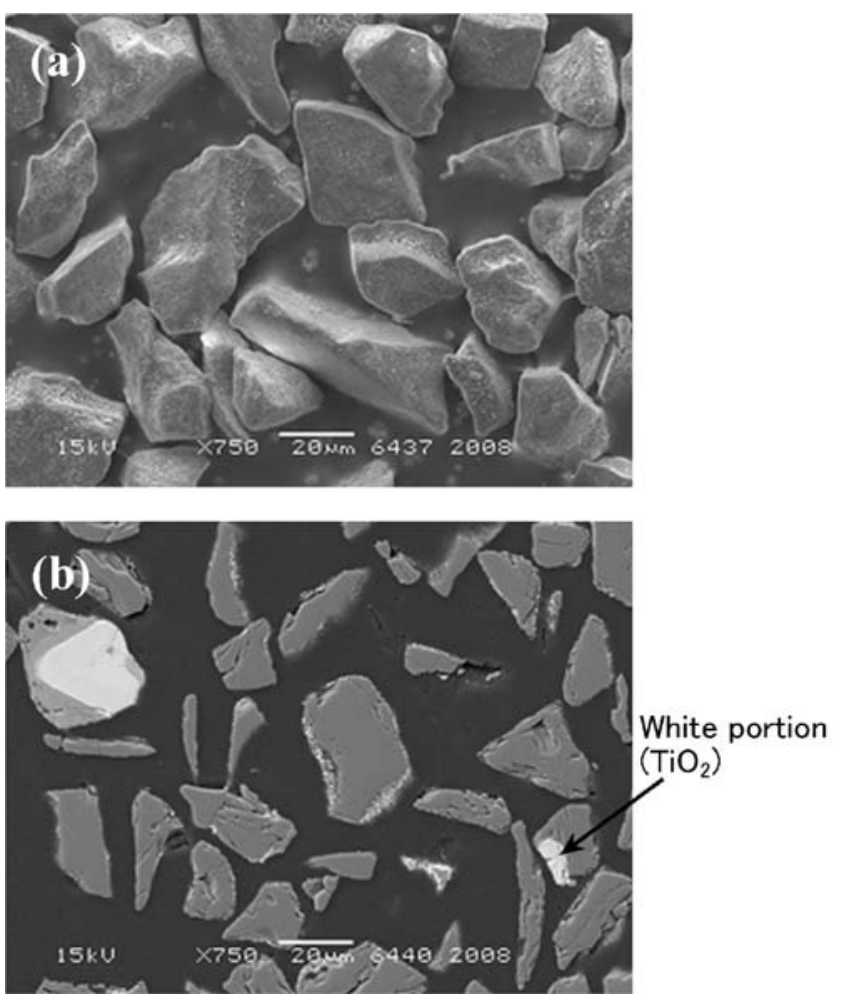

Fig. 4 Surface morphology (a) and cross-sectional micro structure (b) of $\mathrm{Al}_{2} \mathrm{O}_{3}-7.5$ mass $\% \mathrm{TiO}_{2}$ powder.

本研究ではこの低抵抗の誘電体で吸着特性を示すジョン ソン・ラーベックカを発生する皮膜の開発を行なった。

\section{3. セラミック溶射皮膜の体積抵抗率の測定}

\section{1 溶射材料の選定}

ジョンソン・ラーベックタイプの静電吸着力を発現する 誘電膜は、体積抵抗率 $10^{10} \sim 10^{12} \Omega \cdot \mathrm{cm}$ が適切であるとい われている ${ }^{\circ}$ 。この体積抵抗率を得る材料として、既に焼 結セラミックスでは実用化の研究がなされており、 $\mathrm{Al}_{2} \mathrm{O}_{3}$ $\mathrm{TiO}_{2}$. 系材料が有効と報告されている ${ }^{11}$ 。本研究に打いても これらを参考として、高電気抵抗率を有する $\mathrm{Al}_{2} \mathrm{O}_{3}$ を主成 分とし、これに導電材料として $\mathrm{TiO}_{2}$ を $2.5 \mathrm{mass} \% 、 5 \mathrm{mass} \%$ 、 $7.5 \mathrm{mass} \%$ の割合でそれぞれ混合添加した 3 種類の $\mathrm{Al}_{2} \mathrm{O}_{3}$ $\mathrm{TiO}_{2}$ 系溶射材料を用いた。 $\mathrm{Al}_{2} \mathrm{O}_{3}$ は電融粉砕法で製造され、 純度 $99.8 \mathrm{mass} \%$ 、平均粒径 $30 \mu \mathrm{m}$ の粉末を用いた。上記 3 種類の溶射材料と、比較用として出発原料の $\mathrm{Al}_{2} \mathrm{O}_{3}$ 材の 4 種類の溶射皮膜に関して体積抵抗率を測定した。その結果、 室温で体積抵抗率が $10^{10} \sim 10^{12} \Omega \cdot \mathrm{cm}$ の範囲に入る材料を 選定した。

Fig. 4 は、一例として $\mathrm{Al}_{2} \mathrm{O}_{3}-7.5 \mathrm{mass} \% \mathrm{TiO}_{2}$ 溶射材料の表 面と断面写真を示した。

\section{2 溶射条件}

大気プラズマ溶射法（スルザーメテコ社製 UNICOAT- 


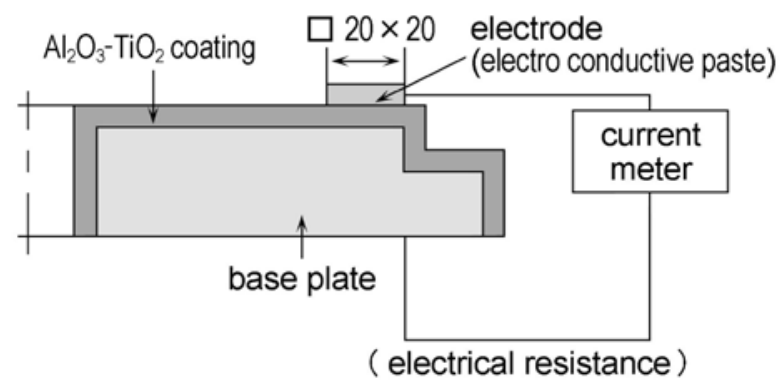

Fig. 5 Schematic diagram of measuring method for electro resistivity.

F4MB プラズマ溶射ガン）を用いて、作動ガスに $\mathrm{Ar}$ と水素 を用い、42KW の出力で溶射距離を $120 \mathrm{~mm}$ に設定し、試 験片を作製した。なお、溶射ガンは 6 軸ロボットに搭載し、

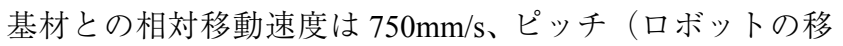
動間隔）は $5 \mathrm{~mm}$ の移動で成膜を行った。

\section{3 $\mathrm{Al}_{2} \mathrm{O}_{3}-\mathrm{TiO}_{2}$ 系溶射皮膜の体積抵抗率の測定方法}

直径 $150 \mathrm{~mm}$ 、厚さ $20 \mathrm{~mm}$ のアルミニウム合金板 (JIS A5052）表面をブラスト処理後、3.2 項の溶射条件で $300 \mu$ $\mathrm{m}$ 厚さの皮膜を形成した後、膜厚が $250 \mu \mathrm{m}$ となるように 研磨仕上げした。その表面粗さは算術平均粗さ $\mathrm{Ra}=0.2 \mu$ $\mathrm{m}$ である。

体積抵抗率の測定は、Fig. 5 に示すように誘電膜表面の $20 \mathrm{~mm}$ x 20mm の部位に導電ペースト（藤倉化成製ドータ イトXA-910）を塗布して電極とし、図に示すように結線 した。誘電層を介し基盤との間に直流電圧 $500 \mathrm{~V}$ を印加し て、微少電流計（アドバンテスト社製 R8340A）を用いて 298K、373K、473K、573K の各温度で漏れ電流を測定し、 その時の電気抵抗值 $(\mathrm{R})$ から、体積抵抗率 $(\rho)$ を次式によ り求めた。

$$
\rho=R A / d
$$

$\rho:$ 体積抵抗率 $(\Omega \cdot \mathrm{cm}) 、 A$ : 電極面積 $\left(\mathrm{cm}^{2}\right)$ 、 $d:$ 溶射皮膜厚さ $(\mathrm{cm}) 、 R$ : 電気抵抗值 $(\Omega)$

$3.4 \mathrm{Al}_{2} \mathrm{O}_{3}-\mathrm{TiO}_{2}$ 系溶射皮膜の体積抵抗率の測定結果

大気プラズマ溶射法により作製した $\mathrm{Al}_{2} \mathrm{O}_{3}-\mathrm{TiO}_{2}$ 系溶射皮 膜の体積低効率の測定結果を Fig. 6 に示す。室温において、 $\mathrm{Al}_{2} \mathrm{O}_{3}$ 単体の皮膜では $1.5 \times 10^{14} \Omega \cdot \mathrm{cm} 、 \mathrm{Al}_{2} \mathrm{O}_{3}-2.5 \mathrm{mass} \% \mathrm{TiO}_{2}$ 皮膜では $1.1 \times 10^{14} \Omega \cdot \mathrm{cm} 、 \mathrm{Al}_{2} \mathrm{O}_{3}-5 \mathrm{mass} \% \mathrm{TiO}_{2}$ 皮膜では 4.6 x $10^{12} \Omega \cdot \mathrm{cm} 、 \mathrm{Al}_{2} \mathrm{O}_{3}-7.5 \mathrm{mass} \% \mathrm{TiO}_{2}$ 皮膜では $7.9 \times 10^{11} \Omega$. $\mathrm{cm}$ を示した。

ジョンソン・ラーベックタイプの静電吸着用の溶射材料 としては、7.5mass\% $\% \mathrm{TiO}_{2}$ を配合した $\mathrm{Al}_{2} \mathrm{O}_{3}$ が適用可能な体 積抵抗率を有することが判った。しかし、これらの皮膜は 温度依存性が認められ、温度上昇と共に抵抗率が減少し、 $373 \mathrm{~K}$ 以上になると $10^{10} \Omega \cdot \mathrm{cm}$ よりも低い測定值が得られ た。一方、 $\mathrm{Al}_{2} \mathrm{O}_{3}-5 \mathrm{mass} \% \mathrm{TiO}_{2}$ 皮膜では、室温での体積抵抗

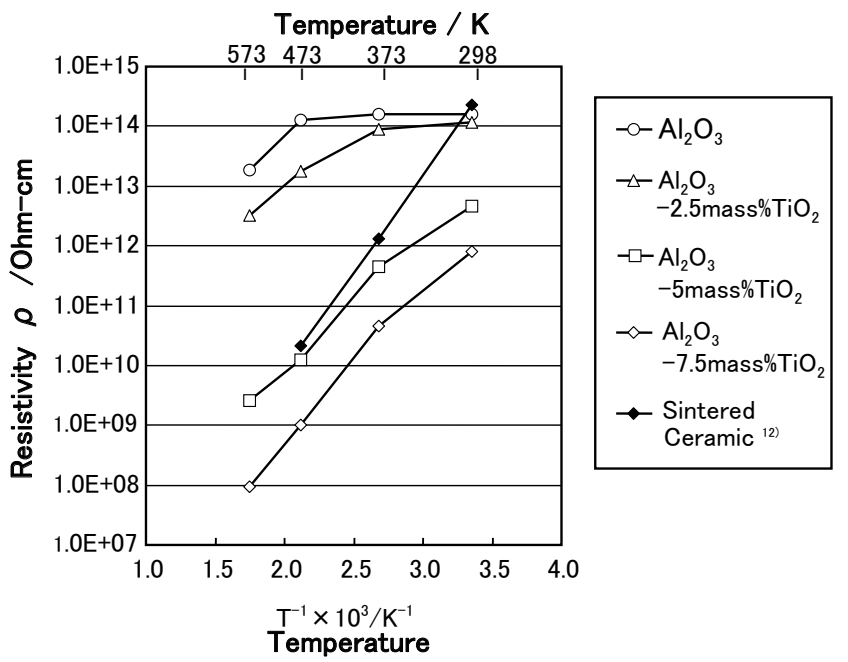

Fig. 6 Relationship between electro resistivity and temperature for each ceramic coatings, compare with sintered ceramics ${ }^{13)}$.

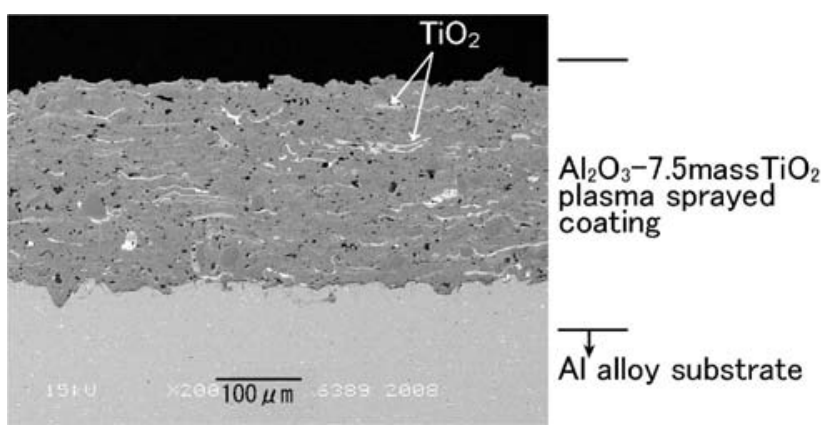

Fig. 7 Cross-sectional SEM back scattered electron image of $\mathrm{Al}_{2} \mathrm{O}_{3}$ $7.5 \mathrm{mass} \% \mathrm{TiO}_{2}$ coating.

率は $4.6 \times 10^{12} \Omega \cdot \mathrm{cm}$ と高く、373K において $10^{11} \Omega \cdot \mathrm{cm}$ 域に低下した。 $5 \mathrm{mass} \%$ と $7.5 \mathrm{mass} \%$ の皮膜では温度依存性 の傾きは同じ傾向を示した。このように体積抵抗率の温度 依存性に関しては異なる傾きとなったが $\mathrm{TiO}_{2}$ を配合した焼 結セラミックのそれと同じ挙動であった ${ }^{12)}$ 。また、高抵抗 の $\mathrm{Al}_{2} \mathrm{O}_{3}$ 単体膜と $\mathrm{Al}_{2} \mathrm{O}_{3}-2.5$ mass $\% \mathrm{TiO}_{2}$ 膜は、室温から $373 \mathrm{~K}$ 付近まではほぼ一定の測定值が、それを超えると温度上昇 に伴って抵抗值が減少した。

これらの結果に基づき、室温でジョンソン・ラー ベック力を発現する可能性のある溶射材料として $\mathrm{Al}_{2} \mathrm{O}_{3}$ $7.5 \mathrm{mass}^{2} \% \mathrm{TiO}_{2}$ 粉末を選定し、その溶射皮膜の基本特性を検 討した。

\section{4. $\mathrm{Al}_{2} \mathrm{O}_{3}-7.5$ mass $\% \mathrm{TiO}_{2}$ 溶射皮膜の基本特性}

\section{1 $\mathrm{Al}_{2} \mathrm{O}_{3}-7.5$ mass $\% \mathrm{TiO}_{2}$ 溶射皮膜の構造}

Fig. 7 に溶射皮膜の断面組織を示す。白色部の導電体で ある $\mathrm{TiO}_{2}$ がラメラ状に分散している。 $\mathrm{Al}_{2} \mathrm{O}_{3}$ 中に導電体で ある $\mathrm{TiO}_{2}$ が張り巡らされて存在する形態となっている。 


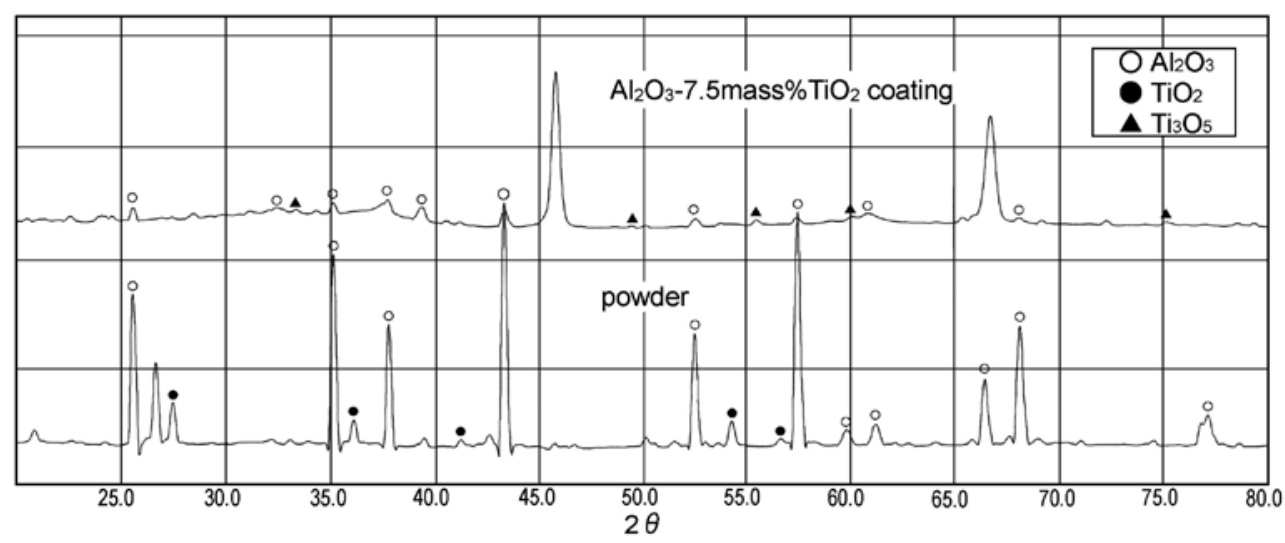

Fig. 8 X-ray diffraction patterns of $\mathrm{Al}_{2} \mathrm{O}_{3}-7.5$ mass $\% \mathrm{TiO}_{2}$ coating and powder.

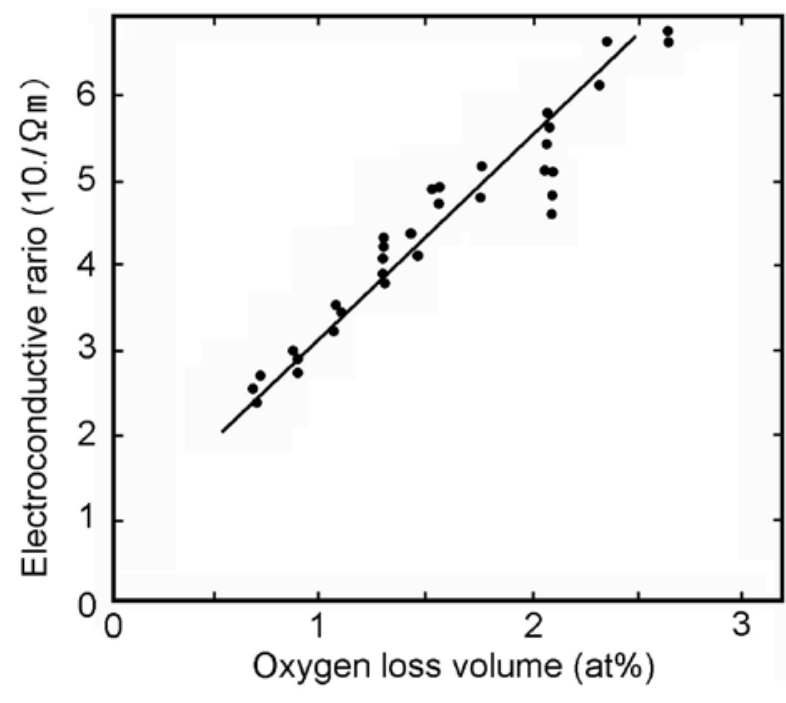

Fig. 9 Relationship between oxygen loss of $\mathrm{TiO}_{2}$ sprayed coating and electro-conductive ratio ${ }^{14)}$.

Fig. 8 はX線回折結果であり、原料粉末と比べると溶射 皮膜の回折図形はブロードになっている。また、原料粉末 では $\mathrm{TiO}_{2}$ のピークが認められたが、溶射皮膜ではそれが減 衰して、それに代わって $\mathrm{Ti}_{3} \mathrm{O}_{5}$ のピークが認められ、 $\mathrm{TiO}_{2}$ から酸素が脱離している様子が確認された。この現象は既

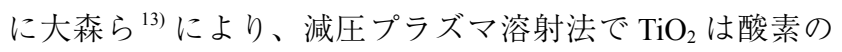
脱離が起こり、 $\mathrm{TiO}_{2}$ の酸素脱離割合と電気伝導率に相互関 係があることが報告されている。

Fig. 9 は減圧プラズマ溶射法で形成した $\mathrm{TiO}_{2}$ 溶射皮膜の 酸素脱離割合と電気伝導率の関係を測定した結果である ${ }^{14)} 。$ 酸素脱離割合が増大すると電気伝導率は高くなる。酸素分 圧の低い減圧プラズマ溶射法で起きる酸素脱離現象が、今 回の実験条件である酸素の存在する大気中でも起きること が確認された。これはプラズマの作動ガスである水素によ る還元作用であると推定される。
Table 1 Dimension of test specimens for several evaluations.

\begin{tabular}{|l|c|}
\hline \multicolumn{1}{|c|}{ Test method } & $\begin{array}{c}\text { Dimension of } \\
\text { specimens }(\mathrm{mm})\end{array}$ \\
\hline Specific heat & Powder \\
\hline Density & $\phi 10 \times 1$ \\
\hline Thermal diffusivity & $\phi 10 \times 1$ \\
\hline Coefficient of thermal expansion & $5 \times 12 \times 1$ \\
\hline 4 point bending & $10 \times 60 \times 1.5$ \\
\hline
\end{tabular}

$4.2 \mathrm{Al}_{2} \mathrm{O}_{3}-7.5 \mathrm{mass} \% \mathrm{TiO}_{2}$ 溶射皮膜の物理的特性の測定結果 前述した皮膜構造を有する溶射皮膜の各種物理的特性を 以下に示す方法で測定した。

$100 \mathrm{~mm} \times 100 \mathrm{~mm} \times 5 \mathrm{~mm}$ の大きさのグラファイト材に $2.5 \mathrm{~mm}$ の厚さで 3.2 項に示す条件で溶射を行い、そのブロッ ク形状の溶射皮膜を Table 1 に示す寸法に加工し、各評価 試験に供した。

皮膜密度は、水中置換法（JIS K7112A）によって、298K で3 回測定し、その平均值をとった。

比熱は、DSC 法によって、Ar ガス気流中で室温と、 373K から $100 \mathrm{~K}$ 毎に $873 \mathrm{~K}$ までの温度で測定した。測定装 置は、TA インスツルメンツ社製 型式 DSC6 示差走査熱量 計である。レーザフラッシュ法によって、真空中（1.3Pa） で室温と、373K から $100 \mathrm{~K}$ 毎に $873 \mathrm{~K}$ までの温度で熱拡散 率を測定した。装置はリガク製 型式 LF/TCM FA8510B レーザフラッシュ法熱定数測定装置を用いた。熱伝導率 $(\lambda)$ を上記の密度 $(\rho)$ 、比熱 $(\mathrm{Cp})$ 、熱拡散率 $(\alpha)$ を用 い次式により算出した。

$\lambda=\rho \times \mathrm{Cp} \times \alpha$

曲げ強度は 4 点曲げ法で行ない破断荷重から算出した。 ヤング率は共振法で測定した。

Table 2 はそれぞれの試験結果を示した。 
Table 2 Test results of several physical properties.

\begin{tabular}{|c|c|c|}
\hline Test methods & Test result & $\begin{array}{c}\text { Sintered ceramic data } \\
\left(\text { TOTO } \mathrm{Al}_{2} \mathrm{O}_{3} \cdot \mathrm{TiO}_{2}\right)\end{array}$ \\
\hline Density & $3380 \mathrm{~kg} / \mathrm{m}^{3}$ & $3600 \mathrm{~kg} / \mathrm{m}^{3}$ \\
\hline Thermal conductivity & $2.99 \mathrm{~W} / \mathrm{m} \cdot \mathrm{K}$ & $13 \mathrm{~W} / \mathrm{m} \cdot \mathrm{K}$ \\
\hline $\begin{array}{c}\text { Coefficient of } \\
\text { thermal expansion }\end{array}$ & $6.04 \times 10^{-6} / \mathrm{K}$ & $8.2 \times 10^{-6} / \mathrm{K}$ \\
\hline Bending strength & $102.6 \mathrm{MPa}$ & $290 \mathrm{MPa}$ \\
\hline Young' s Modulus & $60.4 \mathrm{GPa}$ & $240 \mathrm{GPa}$ \\
\hline
\end{tabular}

Table 2 に示す溶射皮膜の機械的な特性は焼結セラミッ クと比較すると低い值を示した。溶射皮膜の熱伝導率は焼 結セラミックと比較して 4 分の 1 程度であることが判った。 線膨張係数は $6.04 \times 10^{-6} / \mathrm{K}$ で焼結セラミックより若干小さ くなった。

\section{$4.3 \mathrm{Al}_{2} \mathrm{O}_{3}-7.5 \mathrm{mass} \% \mathrm{TiO}_{2}$ 溶射皮膜の比誘電率の測定結果}

直径 $150 \mathrm{~mm}$ 、厚さ $20 \mathrm{~mm}$ のアルミニウム合金板 (JIS $\mathrm{A} 5052$ ）上へ、 $\mathrm{Al}_{2} \mathrm{O}_{3}-7.5$ mass $\% \mathrm{TiO}_{2}$ 粉末により 3.2 項の条 件で $300 \mu \mathrm{m}$ 厚さの皮膜を形成した後、膜厚が $250 \mu \mathrm{m}$ と なるように研磨仕上げし供試材とした。試験は Fig. 10 に 示すように誘電膜表面に直径 $18 \mathrm{~mm}$ の範囲で導電ペースト （ドータイト）を塗布して電極とし、ブリッジ法により、大 気中、室温において、周波数 $100 \mathrm{KHz}$ で静電容量を測定し た。測定装置はインピーダンスアナライザー（アジレント・ テクノロジー社製 型式 HP- 4284A）を用いた。その結果、 皮膜の比誘電率は 11.4 であり、誘電正接は 0.048 であった。

$4.4 \mathrm{Al}_{2} \mathrm{O}_{3}-7.5 \mathrm{mass} \% \mathrm{TiO}_{2}$ 溶射皮膜の静電吸着力の測定結果

$\mathrm{Al}_{2} \mathrm{O}_{3}-7.5$ mass $\% \mathrm{TiO}_{2}$ 溶射皮膜の静電吸着力を測定し た。測定方法はFig. 11 に示すような直径 $150 \mathrm{~mm}$ 、厚さ $20 \mathrm{~mm}$ のアルミニウム合金（JIS A5052） 円盤上へ $\mathrm{Al}_{2} \mathrm{O}_{3}$ $7.5 \mathrm{mass}_{0} \% \mathrm{TiO}_{2}$ 粉末を 3.2 項の条件で $300 \mu \mathrm{m}$ 厚さで皮膜を 形成した後、膜厚が $250 \mu \mathrm{m}$ となるように研磨仕上げし供 試材とした。この供試材表面に直径 $40 \mathrm{~mm}$ 、厚さ $1.2 \mathrm{~mm}$ の 銅板（無酸素銅）を設置し、電極とした。その銅板の中心 から引っ張り試験機に接続した。圧力 $101 \mathrm{~Pa}$ 、室温で直流 電圧 $700 \mathrm{~V}$ を 5 分間印加し、静電吸着させた直後に電源を 切り、銅板を定常速度で引き上げ、その時の引き剥がし荷 重を測定した。その荷重を銅板の面積で除し、静電吸着力 とした ${ }^{11)}$ 。

Fig.12に $\mathrm{Al}_{2} \mathrm{O}_{3}-7.5 \mathrm{mass} \% \mathrm{TiO}_{2}$ 溶射皮膜の静電吸着力試験 結果を示す。比較として $\mathrm{TiO}_{2}$ を含有した $\mathrm{Al}_{2} \mathrm{O}_{3}$ 焼結セラミッ クのデータを示した ${ }^{12)}$ 。

$\mathrm{Al}_{2} \mathrm{O}_{3}-7.5$ mass $\% \mathrm{TiO}_{2}$ 溶射皮膜は $700 \mathrm{~V}$ を印加した場合に $7.2 \mathrm{kPa}$ の静電吸着力を示した。今回測定した電圧の範囲内 では、静電吸着力は電圧と共に直線的に増加する傾向を示

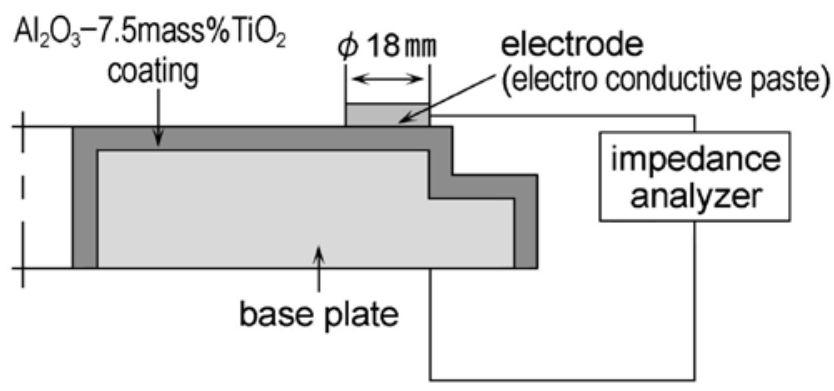

Fig. 10 Schematic diagram of measuring method for dielectric constant. $(100 \mathrm{kHz})$

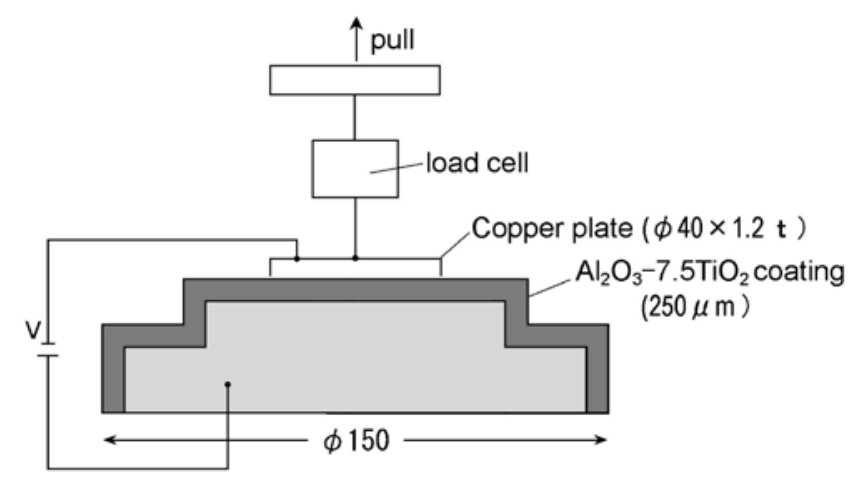

Fig. 11 Schematic diagram of measuring apparatus for electrostatic adsorption force.

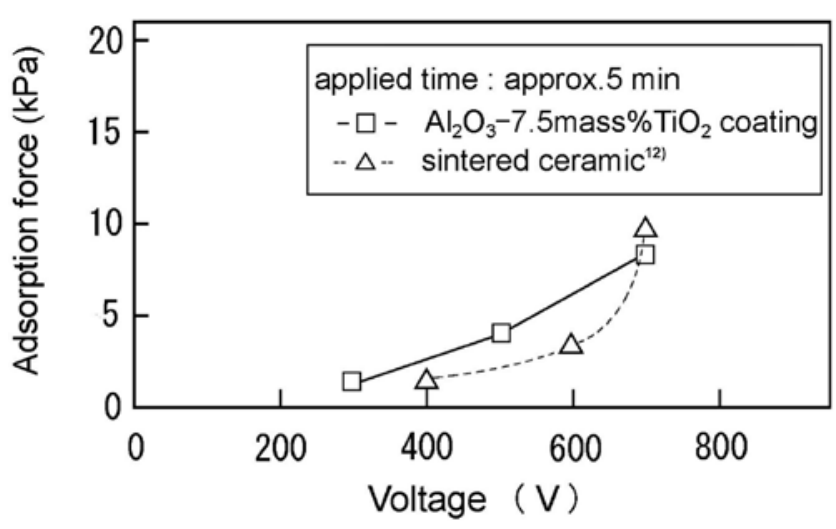

Fig. 12 Relationship between electrostatic adsorption force and applied voltage at room temperature.

した。また、焼結セラミックの吸着データ ${ }^{12)}$ と比較すると、 低電圧の範囲では溶射皮膜の静電吸着力が焼結セラミック より高くなった。また $700 \mathrm{~V}$ を超えると焼結セラミックが 高くなり逆転した。

\section{5. 結言}

本研究では、大気プラズマ溶射法を用いた静電吸着機能 を有するセラミック皮膜の開発を目的に、溶射材料として $\mathrm{Al}_{2} \mathrm{O}_{3}-\mathrm{TiO}_{2}$ 系を選び、そのセラミック溶射皮膜の体積抵抗 
率の測定、各種皮膜特性から検討した。

それらの結果を以下にまとめて示す。

(1) 絶縁材料である $\mathrm{Al}_{2} \mathrm{O}_{3}$ に対して導電体である $\mathrm{TiO}_{2}$ を $7.5 \mathrm{mass} \%$ 混合添加した溶射粉末を用いて、大気プラズ マ溶射した皮膜は、室温から $373 \mathrm{~K} の$ 範囲で $10^{10} \sim 10^{12}$ $\Omega \cdot \mathrm{cm}$ の体積抵抗率を示し、その温度域でジョンソン・ ラーベックタイプの静電吸着が可能な皮膜であること がわかった。

(2) $\mathrm{Al}_{2} \mathrm{O}_{3}-7.5 \mathrm{mass} \% \mathrm{TiO}_{2}$ の皮膜の静電吸着力は室温で $700 \mathrm{~V}$ を印加したとき $7.2 \mathrm{kPa}$ であった。

$\mathrm{Al}_{2} \mathrm{O}_{3}-7.5 \mathrm{mass} \% \mathrm{TiO}_{2}$ 皮膜の機械的特性、および電気的特 性を求めた。機械的特性を焼結セラミックスと比較すると、 溶射皮膜の熱伝導性は低くなり、曲げ強度、ヤング率は低 く線膨張係数は小さいことが得られた。 $100 \mathrm{kHz}$ での比誘電 率は室温において焼結セラミックと同等で 11.4 であること がわかった。

\section{引用文献}

1) 井口忠士、立川俊洋、茅本隆司 : Journal of the vacuum society of Japan, Vol. 45, No.8 p633(2002)
2) 渡部俊也：静電気学会, 23, 4, p180 (1999)

3) P.Singer : Semiconductor International, 18(4), p57(1995)

4) J.Field : Solid State Technology, 37(9), p91(1994)

5) 清水 孝: Journal of the vacuum society of Japan, Vol. 45, No.8 p643(2002)

6) 玉川孝一 : Journal of the vacuum society of Japan, Vol. 45, No.8 p647(2002)

7) 渡部俊也、北林徹夫、藤本正之：静電気学会講演春季大会講 演論文集 p311 - (1988)

8) Johnsen and Rahbek : J. Inst. Electr. Eng, 61, p713(1923)

9) L.D.Hartsough : Solid Static Technology, No.1, p187 (1986)

10）久保田芳宏：電子材料, 1996 年 7 月号別冊, p2

11) T. Watanabe, T. Kitabayashi : J. of the Ceramic Society of Japan 100 (1) $\mathrm{p} 1(1992)$

12）渡部俊也：応用機械工学、1989 年 5 月号、p128

13）大森明、朴景采：表面技術 41 (1990) 1004

14) A. Ohmori, K. C. Park, M. Inuzuka, Y. Arata, K. Inoue, N. Iwamoto : Thin Solid. Films : 201 (1991) 1

15) 静電ウエハーチャック：TOTO 株式会社カタログ No. 687(1993) 